\title{
Changes in Plasma Sex Steroid and Cortisol Levels during Annual Reproductive Cycle of Ribbed Gunnel, Dictyosoma burgeri
}

\author{
In Joon Hwang ${ }^{1}$, Sung Yeon Kim¹, Hyung Bae $\mathrm{Kim}^{2}$ and Hea Ja Baek, \\ ${ }^{1}$ Genetics and Breeding Research Center, National Fisheries Research and Development Institute, \\ Geoje 656-842, Korea \\ ${ }^{2}$ Dept. of Marine Bio-resources, Gangwon Provincial College, Gangnung 210-804, Korea \\ ${ }^{3}$ Dept. of Marine Biology, Pukyong National University, Busan 608-737, Korea
}

\begin{abstract}
We investigated the changes in plasma sex steroid hormones, testosterone (T), estradiol-17 $\beta$ ( $\left.\mathrm{E}_{2}\right), 17,20 \beta$ -dihydroxy-4-pregnen-3-one (17 $\alpha 20 \beta$ P), 11-ketotestosterone (11KT) and cortisol levels from ribbed gunnel, Dictyosoma burgeri in associated with annual reproductive cycle. The gonadosomatic index (GSI) of females increased from November, peaked in February and decreased rapidly from March. The GSI of males also increased from November, peaked in January and then decreased gradually. In females, $\mathrm{E}_{2}$ levels increased and remained high from December to February. The levels of $\mathrm{T}$ showed a similar tendency and correlated $\left(r_{s}=0.898, \mathrm{p}<0.01\right)$ with $\mathrm{E}_{2}$ levels. The levels of $17 \alpha 20 \beta \mathrm{P}$ increased rapidly in February $(4.78 \pm 1.01 \mathrm{ng} / \mathrm{ml})$ and peaked in July $(5.08 \pm 0.65 \mathrm{ng} / \mathrm{ml})$. Cortisol level was peaked in March and correlated with $17 \alpha 20 \beta \mathrm{P}$ levels $\left(r_{s}=0.696, \mathrm{p}<0.01\right)$. In males, the levels of $\mathrm{T}$ was peaked in January and then decreased rapidly. The levels of $11 \mathrm{KT}$ were remained high from October to January. On the other hand, the levels of $17 \alpha 20 \beta \mathrm{P}$ fluctuated during reproductive cycle. These results suggest that plasma sex steroids in ribbed gunnels have annual periodicity, and that cortisol may involve in maturation of females.
\end{abstract}

Key words : Sex steroid, Cortisol, Reproductive cycle, Ribbed gunnel

\section{INTRODUCTION}

Reproduction of fish is regulated by endocrine system through hypothalamus-pituitary-gonad axis and controlled by environmental factors such as water temperature and photoperiod (Modesto \& Canario, 2003; Nagahama et al., 1994). Sex steroids from gonad play an important role during reproductive cycle and the relationship between reproductive cycle and plasma sex steroid hormones has been well documented in a number of teleosts including freshwater and marine species (Stequert et al., 2001; Larsson et al., 2002; Koya et al., 2003). Until now, estradiol-17 $\beta\left(\mathrm{E}_{2}\right)$, as a major sex steroid induces the vitellogenesis, vitellogenin uptake from liver to oocytes

\footnotetext{
${ }^{\dagger}$ Corresponding author: Hea Ja Baek, Dept. of Marine Biology, Pukyong National University, Busan 608-737, Korea. Phone: +8251-629-5924, Fax: +82-51-629-5931, E-mail: hjbaek@pknu.ac.kr
}

in females. After vitellogenesis, progestins such as $17 \alpha$, $20 \beta$-dihydroxy-4-pregnen-3-one (17 $\alpha 20 \beta \mathrm{P})$ and/or $17 \alpha$, $20 \beta$,21-trihydroxy-4-pregnen-3-one (17 $\alpha 20 \beta 21 \mathrm{P})$ induce final oocyte maturation including germinal vesicle breakdown (GVBD) and ovulation as the production of $E_{2}$ decreases (Nagahama et al., 1994; Patiño \& Sullivan, 2002). In males, testosterone (T) and 11-ketotestosterone $(11 \mathrm{KT})$ induce spermatogenesis and secondary sexual characteristics (Borg, 1994; Schulz et al., 2010).

Apart from sex steroid hormones, the representative corticosteroid, cortisol is produced from cholesterol by the adrenal cortex and increase in plasma cortisol levels is used as a major marker for stress responses (Bonga, 1997; Mommsen et al., 1999). Recently, Milla and colleagues reported that the levels of various corticosteroids including cortisol are higher during maturation stage than during immature stage in many teleost fish species; the authors 
suggested that corticosteroids may be actors of reproduction in several fish species (Milla et al., 2009). Moreover, there are some reports that increase in plasma cortisol levels during pre-spawning or spawning period although these results are controversial among teleost species (Kusakabe et al., 2003; Noaksson et al., 2005; Westring et al., 2008).

The ribbed gunnel, Dictyosoma burgeri is an intertidal teleost species distributed to coastal waters of Korea and Japan (Kim et al., 2001). After spawning, males guard spawned eggs attached to rocks (Shiogaki \& Dotsu, 1972). Seasonal gonadal development and histological observation have been described in detail for the Jeju, Korea (Jin et al., 2007) however no information is available on seasonal changes of endocrine characteristics during annual reproductive cycle. The purpose of the present study was to investigate changes in plasma levels of $\mathrm{T}, \mathrm{E}_{2}, 17 \alpha 20 \beta \mathrm{P}$ and cortisol from females and $\mathrm{T}, 17 \alpha 20 \beta \mathrm{P}, 11 \mathrm{KT}$ and cortisol from males and obtain insights on their roles in annual reproductive cycle of ribbed gunnel.

\section{MATERIALS AND METHODS}

\section{Experimental fish}

Adult male and female ribbed gunnels were collected by fishing trap in the coastal waters of Dadaepo, Busan, Korea from August 2002 to July 2003, except June 2003, due to problems of capture. And there were no males in March 2003. Fish were anesthetized in $0.1 \%$ 2-phenoxyethanol in seawater and blood was immediately collected from caudal artery with a heparinized $2 \mathrm{ml}$ syringe. Blood samples were centrifuged at 4,000 g for $10 \mathrm{~min}$, then plasma were collected and stored at $-80^{\circ} \mathrm{C}$ until radioimmunoassay (RIA) was performed. Total length $(\mathrm{cm})$ and standard length $(\mathrm{SL}, \mathrm{cm})$ was measured to nearest $0.01 \mathrm{~cm}$. Body weight $(\mathrm{BW}, \mathrm{g})$ and gonad weight $(\mathrm{GW}, \mathrm{g})$ was measured to the nearest $0.01 \mathrm{~g}$ for calculation of gonadosomatic indices (GSI) according to $\mathrm{GSI}=100 \cdot \mathrm{GW} \cdot \mathrm{BW}^{-1}$.

\section{Radioimmunoassay}

Steroids from plasma were extracted twice in $2 \mathrm{ml}$ diethyl ether, dried under nitrogen gas and resuspended in phosphate buffer ( $\mathrm{pH}=7.5)$. Plasma $\mathrm{E}_{2}, \mathrm{~T}, 17 \alpha 20 \beta \mathrm{P}$, $11 \mathrm{KT}$ and cortisol were measured by radioimmunoassay (RIA) according to the Kobayashi's method (Kobayashi et al., 1987). Anti sera for $\mathrm{E}_{2}, \mathrm{~T}, 17 \alpha 20 \beta \mathrm{P}, 11 \mathrm{KT}$ and cortisol were purchased from Cosmo-Bio Co. Ltd. (Tokyo, Japan). Non-radioactive steroid standards were purchased from Steraloids Inc. (Wilton, NH, USA). Radiolabeled steroids $\left(\left[{ }^{3} \mathrm{H}\right]-\mathrm{T},\left[{ }^{3} \mathrm{H}\right]-\mathrm{E}_{2},\left[{ }^{3} \mathrm{H}\right]-11 \mathrm{KT}\right.$ and $\left[{ }^{3} \mathrm{H}\right]-$ cortisol) were purchased from Amersham Lifesciences (Piscataway, NJ, USA) and radio-labeled $17 \alpha 20 \beta \mathrm{P}$ was prepared from $\left[{ }^{3} \mathrm{H}\right]-17 \alpha$-hydroxyprogesterone (Amersham Lifesciences) by enzymatic conversion as described by Scott's method (Scott et al., 1982) and separated from the parent compound by thin layer chromatography. The sensitivities of the assay were $12.5 \mathrm{pg} / \mathrm{ml}, 10 \mathrm{pg} / \mathrm{ml}$, $16 \mathrm{pg} / \mathrm{ml}, 10 \mathrm{pg} / \mathrm{ml}$ and $22.5 \mathrm{pg} / \mathrm{ml}$ for $\mathrm{E}_{2}, \mathrm{~T}, 11 \mathrm{KT}$, $17 \alpha 20 \beta \mathrm{P}$ and cortisol, respectively. The intra- and inter-assay coefficients of variations at $50 \%$ binding were $3.4 \%(n=3)$ and $11.5 \%(n=6)$ for $E_{2}, 2.3 \%(n=3)$ and $12.5 \%(\mathrm{n}=6)$ for $\mathrm{T}, 3.9 \%(\mathrm{n}=4)$ and $7.3 \%(\mathrm{n}=8)$ for $11 \mathrm{KT}, 3.2 \%(\mathrm{n}=4)$ and $9.5 \%(\mathrm{n}=8)$ for $17 \alpha 20 \beta \mathrm{P}$ and $2.8 \%(n=5)$ and $8.1 \%(n=6)$ for cortisol.

\section{Statistics}

All data from steroid levels were expressed as means with the standard error of the means (SEM) and tested for normality using the Kolmogorov-Smirnov test using SPSS software (version 17.0) for Windows (SPSS, Chicago, IL, USA). However, the assumptions of normality and equal variance were failed, and then non-parametric Kruskal-Wallis test was performed and, when significant, followed by Bonferroni's adjustment for comparison of monthly mean values of plasma steroid levels. A value of $\mathrm{P}<0.05$ was considered statistically significant. In the correlation analysis among plasma steroid levels, we examined Spearman's rank correlation test followed by 
multiple comparisons with each steroid levels. Statistical significance was set at $\alpha=0.05$.

\section{RESULTS}

\section{Changes in GSI during reproductive cycle}

During the sampling period, 66 females and 67 males were captured for this study and monthly distribution of their SL and BW are listed in Table 1. GSI of females increased since November, peaked in February $(11.10 \pm 2.74)$ and then decreased rapidly in March (1.05 \pm 0.23 , Fig. 1). In males, GSI increased since November, peaked in January $(0.46 \pm 0.25)$, then decreased gradually until April $(0.15 \pm 0.05)$ and remained at a low level until July $(0.05 \pm 0.01 \sim 0.07 \pm 0.01)$.

\section{Plasma sex steroids and cortisol levels of females} during reproductive cycle

Plasma $\mathrm{T}$ levels of females were low in August and September $(0.95 \pm 0.06$ and $0.87 \pm 0.07 \mathrm{ng} / \mathrm{ml}$, respectively), increased from November $(2.74 \pm 0.58 \mathrm{ng} / \mathrm{ml})$ and peaked in January (13.12 $\pm 6.46 \mathrm{ng} / \mathrm{ml}$, Fig. 2). T levels then decreased rapidly in March $(0.64 \pm 0.11 \mathrm{ng} / \mathrm{ml})$ and remained

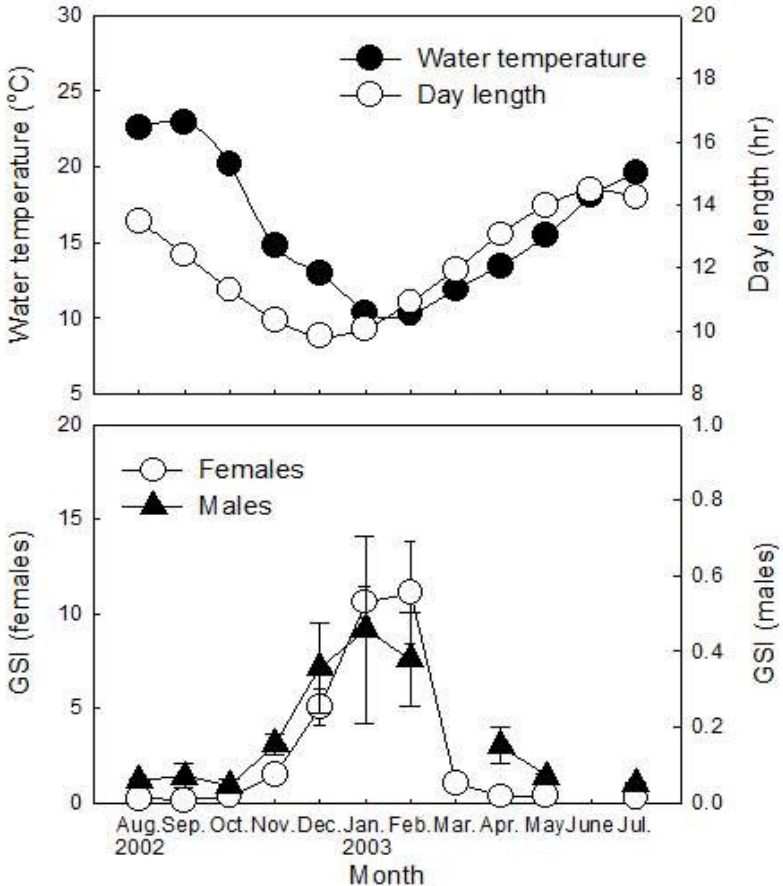

Fig. 1. Monthly changes in the mean water temperature, day length and gonadosomatic index (GSI) of male and female ribbed gunnel. Data represent means $\pm \mathrm{SE}$.

at a low level until July $(0.64 \pm 0.08 \sim 1.41 \pm 0.21 \mathrm{ng} / \mathrm{ml})$. Plasma $E_{2}$ levels of females were low from August to November $(1.28 \pm 0.25 \sim 3.03 \pm 0.68 \mathrm{ng} / \mathrm{ml})$ and increased

Table 1. Mean of standard length (SL) and body weight (BW) used in the present study and number of fish

\begin{tabular}{|c|c|c|c|c|c|c|}
\hline & \multicolumn{3}{|c|}{ Females } & \multicolumn{3}{|c|}{ Males } \\
\hline & SL (cm) & BW (g) & $\mathrm{n}$ & $\mathrm{SL}(\mathrm{cm})$ & BW (g) & $\mathrm{n}$ \\
\hline Aug., 2002 & $22.20 \pm 0.76$ & $66.41 \pm 7.82$ & 6 & $23.72 \pm 1.21$ & $81.07 \pm 13.23$ & 6 \\
\hline Sep. & $21.08 \pm 2.82$ & $62.71 \pm 26.54$ & 4 & $23.52 \pm 1.38$ & $82.03 \pm 14.29$ & 6 \\
\hline Oct. & $21.53 \pm 1.82$ & $64.72 \pm 16.56$ & 3 & $24.83 \pm 1.09$ & $87.76 \pm 8.65$ & 3 \\
\hline Nov. & $21.41 \pm 1.17$ & $67.17 \pm 10.75$ & 8 & $22.14 \pm 0.57$ & $64.27 \pm 4.30$ & 11 \\
\hline Dec. & $20.60 \pm 1.07$ & $53.36 \pm 10.05$ & 9 & $15.72 \pm 2.82$ & $42.58 \pm 8.83$ & 5 \\
\hline Jan., 2003 & $18.53 \pm 0.59$ & $42.81 \pm 3.85$ & 13 & $18.72 \pm 0.81$ & $40.32 \pm 5.49$ & 5 \\
\hline Feb. & $18.36 \pm 1.34$ & $42.61 \pm 11.13$ & 5 & $18.89 \pm 0.72$ & $36.38 \pm 3.92$ & 8 \\
\hline Mar. & $22.03 \pm 0.52$ & $56.95 \pm 4.67$ & 3 & - & - & 0 \\
\hline Apr. & $22.80 \pm 1.00$ & $76.42 \pm 9.67$ & 8 & $22.25 \pm 0.91$ & $66.67 \pm 9.93$ & 8 \\
\hline May & $26.25 \pm 1.25$ & $103.68 \pm 11.76$ & 2 & $23.09 \pm 1.06$ & $70.28 \pm 9.33$ & 7 \\
\hline June & - & - & 0 & - & - & 0 \\
\hline July & $22.80 \pm 0.33$ & $63.80 \pm 0.73$ & 5 & $22.41 \pm 0.77$ & $67.49 \pm 8.21$ & 8 \\
\hline Total & & & 66 & & & 67 \\
\hline
\end{tabular}



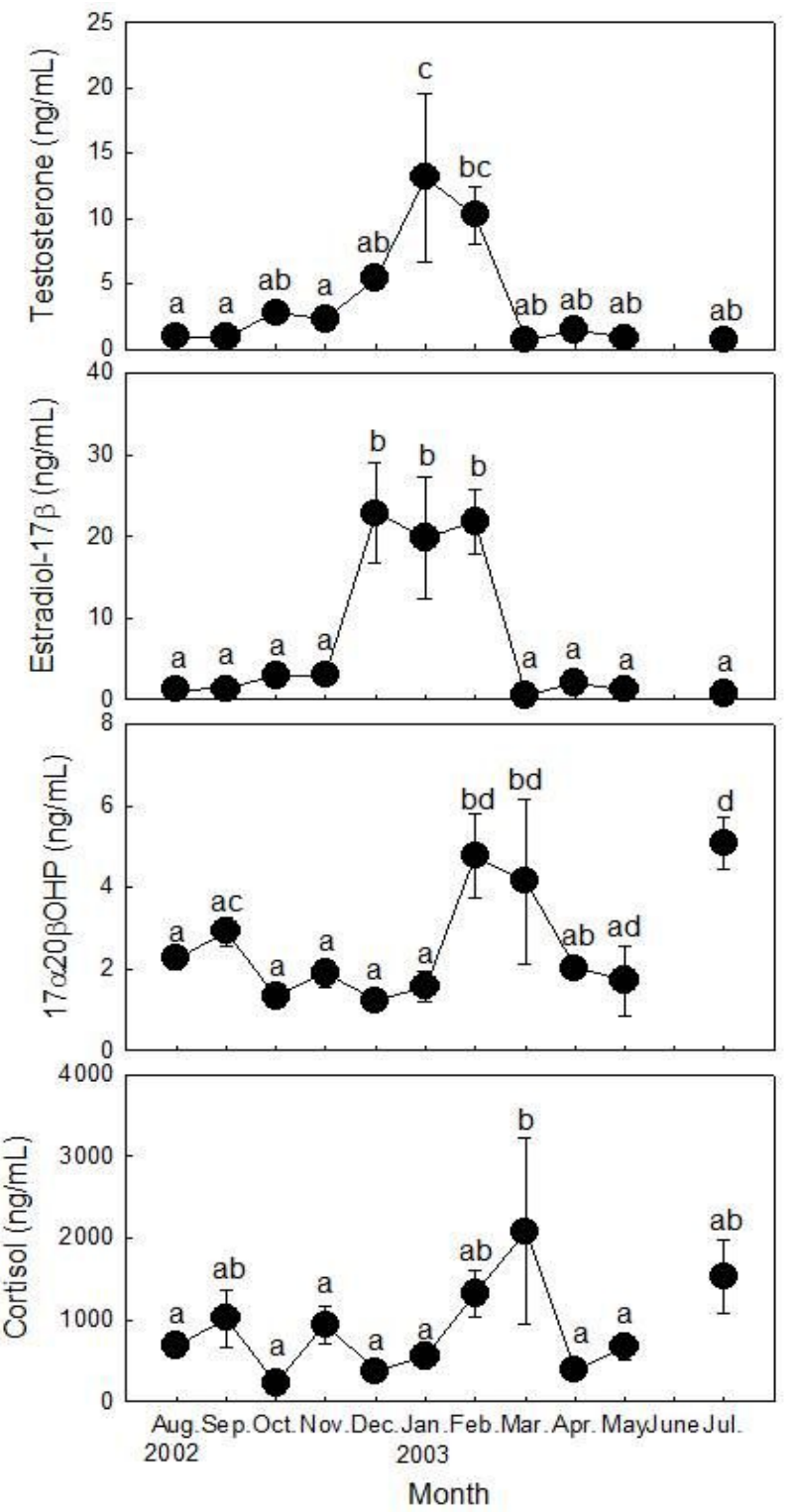

Fig. 2. Plasma levels of $\mathbf{T}, \mathbf{E}_{2}, 17 \alpha 20 \beta \mathbf{P}$ and cortisol during reproductive cycles of the ribbed gunnel females. Data represent means \pm SE. Different letters denote statistically significant differences among the groups $(p<0.05)$.

rapidly and remained at a high level from December to February $(19.81 \pm 7.46 \sim 22.85 \pm 6.18 \mathrm{ng} / \mathrm{ml})$. $\mathrm{E}_{2}$ levels then decreased rapidly in March $(0.53 \pm 0.09 \mathrm{ng} / \mathrm{ml})$ and remained at a low level until July $(0.78 \pm 0.06 \sim 2.06 \pm 0.80 \mathrm{ng} / \mathrm{ml})$. Plasma $17 \alpha 20 \beta \mathrm{P}$ levels of females were low from August to January $(1.23 \pm 0.22 \sim 2.93 \pm 0.35 \mathrm{ng} / \mathrm{ml})$, increased
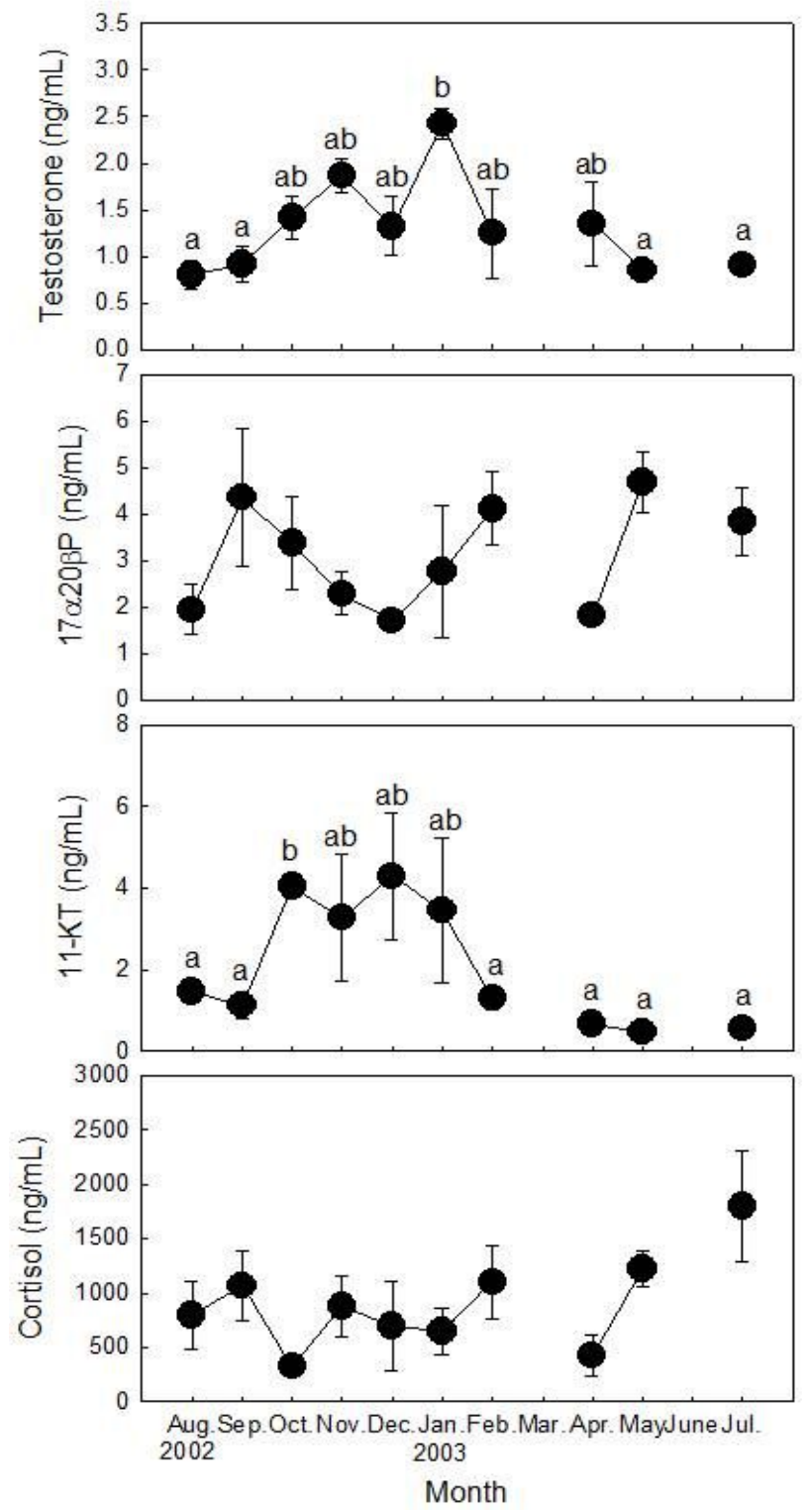

Fig. 3. Plasma levels of T, $17 \alpha 20 \beta \mathbf{P}, 11-\mathrm{KT}$ and cortisol during reproductive cycles of the ribbed gunnel males. Data represent means \pm SE. Different letters denote statistically significant differences among the groups $(p<0.05)$.

rapidly from February $(4.78 \pm 1.01 \mathrm{ng} / \mathrm{ml})$ and remained at a high level in March $(4.15 \pm 2.02 \mathrm{ng} / \mathrm{ml})$. Then, $17 \alpha 20 \beta$ P levels decreased until April $(2.01 \pm 0.12 \mathrm{ng} /$ $\mathrm{ml})$ but increased in July $(5.08 \pm 0.65 \mathrm{ng} / \mathrm{ml})$ as the highest level. Plasma cortisol levels of females fluctuated from August to December $(221.33 \pm 65.90 \sim 1,017.87 \pm 351.52$ 

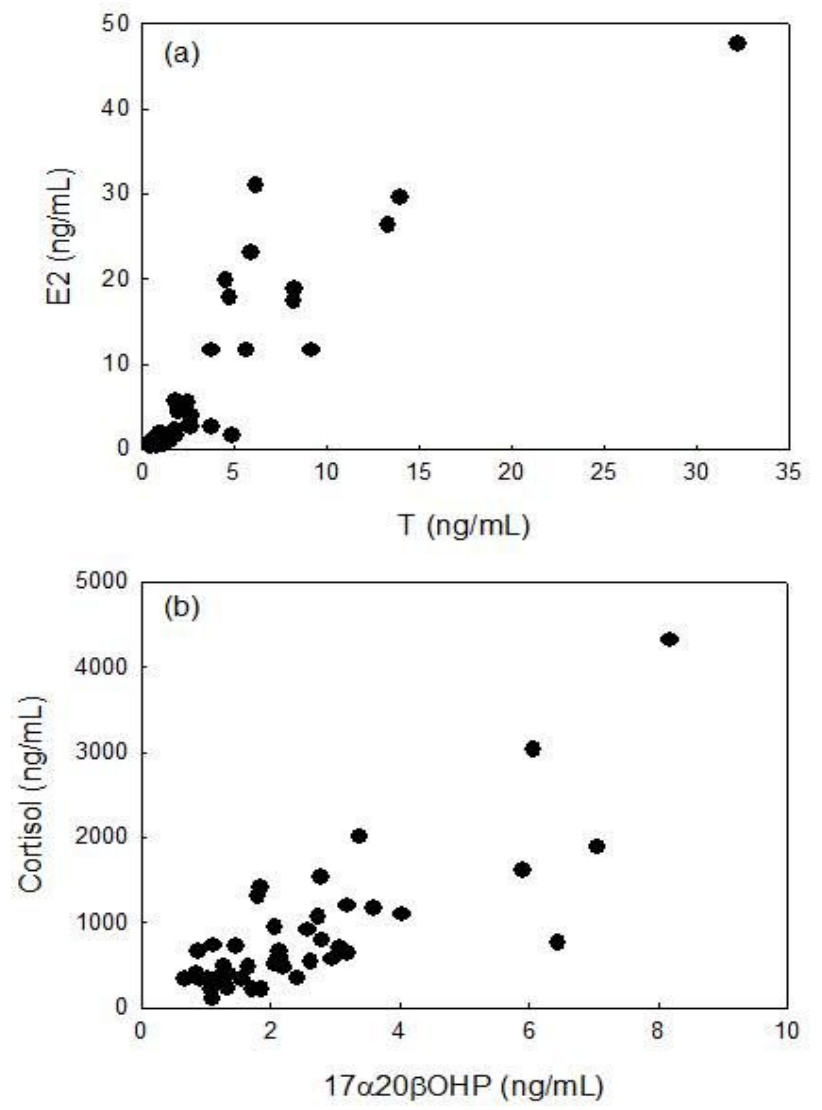

Fig. 4. Relationship between plasma (a) $\mathbf{T}$ and $\mathrm{E}_{2}$ levels, (b) $17 \alpha$ $20 \beta P$ and cortisol levels from female ribbed gunnel during reproductive cycle. The correlation between plasma $\mathrm{T}$ and $\mathrm{E}_{2}$ levels significant $\left(r_{s}=0.898, \mathrm{p}<0.01\right), 17 \alpha 20 \beta \mathrm{P}$ and cortisol levels $\left(r_{s}=0.696, \mathrm{p}<0.01\right)$.

$\mathrm{ng} / \mathrm{ml}$ ), began to increase in January and peaked in March $(2,081.07 \pm 1,140.02 \mathrm{ng} / \mathrm{ml})$. Cortisol level decreased rapidly in April $(386.56 \pm 70.50 \mathrm{ng} / \mathrm{ml})$ and increased again in May $(666.93 \pm 150.44 \mathrm{ng} / \mathrm{ml})$ and July $(1,525.76 \pm$ $446.93 \mathrm{ng} / \mathrm{ml})$.

There were highly significant correlations between plasma $\mathrm{T}$ and $\mathrm{E}_{2}$ levels $\left(r_{s}=0.898, \mathrm{p}<0.01\right.$, Spearman rank correlation), between plasma $17 \alpha 20 \beta \mathrm{P}$ and cortisol levels $\left(r_{s}=0.696, \mathrm{p}<0.01\right.$, Spearman rank correlation) in female ribbed gunnel (Fig. 4).

3. Plasma sex steroids and cortisol levels of males during reproductive cycle
Plasma T levels of males increased from September to November, decreased in December and peaked in January (2.43 $\pm 0.17 \mathrm{ng} / \mathrm{ml}$, Fig. 3). T levels decreased rapidly in February $(1.25 \pm 0.48 \mathrm{ng} / \mathrm{ml})$ and remained low levels in May and July $(0.85 \pm 0.12$ and $0.91 \pm 0.05 \mathrm{ng} / \mathrm{ml}$, respectively). Plasma $17 \alpha 20 \beta$ P levels were low in August $(1.95 \pm 0.53 \mathrm{ng} / \mathrm{ml})$, increased rapidly in September $(4.35 \pm$ $0.31 \mathrm{ng} / \mathrm{ml})$ and decreased gradually until December $(1.72 \pm 0.12 \sim 3.38 \pm 1.00 \mathrm{ng} / \mathrm{ml})$. Then $17 \alpha 20 \beta \mathrm{P}$ levels increased again in January $(2.76 \pm 1.42 \mathrm{ng} / \mathrm{ml})$ and February $(4.11 \pm 0.78 \mathrm{ng} / \mathrm{ml}) .17 \alpha 20 \beta \mathrm{P}$ levels were low in April $(1.70 \pm 0.23 \mathrm{ng} / \mathrm{ml})$ and peaked in May $(4.67 \pm 0.66 \mathrm{ng} / \mathrm{ml})$. In July, $17 \alpha 20 \beta \mathrm{P}$ levels decreased again $(3.84 \pm 0.72$ $\mathrm{ng} / \mathrm{ml})$. Plasma $11 \mathrm{KT}$ levels were low in August and September $(1.12 \pm 0.31 \sim 1.45 \pm 0.22 \mathrm{ng} / \mathrm{ml})$ and maintained high levels from October to January $(3.27 \pm 1.55 \sim 4.28 \pm 1.53$ $\mathrm{ng} / \mathrm{ml})$. Then, $11 \mathrm{KT}$ levels decreased and maintained low levels from February to July $(0.56 \pm 0.08 \sim 1.29 \pm 0.27$ $\mathrm{ng} / \mathrm{ml}$ ). Plasma cortisol levels were high in August and September, decreased in October as the lowest level $(323.20 \pm 18.40 \mathrm{ng} / \mathrm{ml})$. Cortisol levels remained at high levels from November to February (647.60 \pm 211.92 $1,102.67 \pm 339.03 \mathrm{ng} / \mathrm{ml})$ and decreased in April (479.80土 $238.28 \mathrm{ng} / \mathrm{ml}$ ). Then, cortisol levels increased again in May and peaked in July $(1,794.40 \pm 509.09 \mathrm{ng} / \mathrm{ml})$.

\section{DISCUSSION}

The spawning periods of ribbed gunnel were considered from January to February; $17 \alpha 20 \beta$ P levels of females and GSI of both females and males were high during this period. $E_{2}$ levels of female ribbed gunnel were high from December to February during spawning period and were very low throughout most of the year. These were coincident with $\mathrm{T}$ levels and these two steroids were significantly positively correlated. Similar results have been reported in other fish species (Mori et al., 2003; García-López et al., 2006). In general, plasma $E_{2}$ levels increase during vitellogenesis and decrease during 
final oocyte maturation stage by production of progestins such as $17 \alpha 20 \beta \mathrm{P}$ or $17 \alpha 20 \beta 21 \mathrm{P}$ in many teleost species (Nagahama et al., 1994; Patiño \& Sullivan, 2002). Although the role of $\mathrm{T}$ on reproduction of female fish was not identified clearly, the correlation between $T$ and $E_{2}$ has been attributed to the role of $\mathrm{T}$ as a precursor to $E_{2}$ (Shiogaki \& Dotsu, 1972; Matsuyama et al., 1988). However, plasma $\mathrm{T}$ and $\mathrm{E}_{2}$ levels from female ribbed gunnel were maintained highly in February when GSI was the highest value and $17 \alpha 20 \beta \mathrm{P}$ began to increase. In the view of sexual behavior, ribbed gunnel is nestbuilding species (Shiogaki \& Dotsu, 1972). Desjardins and colleagues also reported that females are more aggressive than males and have higher plasma $\mathrm{T}$ levels than their mating males, suggesting a role for $\mathrm{T}$ in female aggression (Desjardins et al., 2008). The results for high levels of $\mathrm{T}$ during spawning period suggest that $\mathrm{T}$ may promote aggressive and nest-building behavior in female ribbed gunnel although the role of $\mathrm{T}$ in this aspect of female has not been investigated. In Eurasia perch, Perca fluviatilis, plasma $\mathrm{E}_{2}$ levels also increased continuously prior to GVBD and decreased sharply after GVBD (Fontain et al., 2003; Migaud et al., 2003). In addition, our previous study reported that synthesis of $E_{2}$ metabolites increased as oocyte diameter increased in mature oocytes (germinal vesicle migratory stage) from ribbed gunnel (Hwang \& Baek, 2010). Therefore, we suspect $E_{2}$ may regulate not only vitellogenesis but final maturation process in ribbed gunnel although further studies should be conducted.

Plasma levels of $17 \alpha 20 \beta \mathrm{P}$ from females began to increase in February and then decreased until May. We consider $17 \alpha 20 \beta \mathrm{P}$ may be a maturation inducing steroid in this species with comparison of changes in GSI. Interestingly, the highest level of $17 \alpha 20 \beta \mathrm{P}$ was detected in July although there was a high value in spawning period. In July, GSI and both of $\mathrm{T}$ and $\mathrm{E}_{2}$ levels were low. The reason is not clear yet. The action of $17 \alpha 20 \beta \mathrm{P}$ may be involved in other physiological role rather than reproduction in July. According to Antonopoulou and colleagues, $17 \alpha 20 \beta \mathrm{P}$ may have a novel hormonal activity such as stimulating meiotic division of the next year's gametes (Antonopoulou et al., 2011). In a recent study, Jin and colleagues reported that the ovarian developmental stage of ribbed gunnel in July was recovery stage; most ovarian follicles consist of oocytes at the perinucleolous stage (Jin et al., 2007). Therefore, the peak of $17 \alpha 20 \beta \mathrm{P}$ level in July would be explained as possible regulation of $17 \alpha 20 \beta \mathrm{P}$ on the meiotic division of oocyets. However, we should conduct histological observation of ovary and other markers for meiotic division as suggested by Miura and colleagues (Miura et al., 2007). Meanwhile, it is also possible to consider that $17 \alpha 20 \beta \mathrm{P}$ is produced at other tissue besides ovary. Interrenal and gills are capable of producing $17 \alpha 20 \beta \mathrm{P}$ in vitro and the presence of $20 \beta$-hydroxysteroid dehydrogenase (HSD), a crucial enzyme for conversion to $17 \alpha 20 \beta$ P were identified (Sangalang \& Freeman, 1988; Ebrahimi et al., 1996; Hoffmann \& Oris, 2006). However, we have insufficient evidence at this point since we did not confirm the production of $17 \alpha 20 \beta \mathrm{P}$ from gills or interrenal tissues. Conclusively, we suspect that the peak of $17 \alpha 20 \beta \mathrm{P}$ level in July which four months after spawning season will be related to meiotic division of ovarian development.

In male ribbed gunnel, GSI increased since October and was the highest value in January and plasma $\mathrm{T}$ levels were also the highest value in January. 11KT levels were high from October to January with fluctuations and then decreased until July. However, $17 \alpha 20 \beta \mathrm{P}$ levels decreased from September until December and then increased until February although there were high fluctuations during annual period. In general, plasma levels of $\mathrm{T}$ and $11 \mathrm{KT}$ are the highest during spermatogenesis in most teleost species and $17 \alpha 20 \beta \mathrm{P}$ is the highest at during spermiation (Jensen et al., 2001; Scott et al., 2010). In the present study, however, there was no significant correlation between $\mathrm{T}$ and $11 \mathrm{KT}$ as reported 
by other fish species (Jensen et al., 2001, Mori et al., 2003). Nevertheless, levels of $\mathrm{T}$ and $11 \mathrm{KT}$ were maintained high levels during period when GSI was high, and these results suggested that both of $\mathrm{T}$ and $11 \mathrm{KT}$ may regulate spermatogenesis in ribbed gunnel. On the other hand, changes in plasma levels of $17 \alpha 20 \beta \mathrm{P}$ were quite different with changes of $\mathrm{T}$ or $11 \mathrm{KT}$. Although $17 \alpha 20 \beta \mathrm{P}$ levels increased from December to February, higher levels than this period were observed in September and May. The reason for high levels of $17 \alpha 20 \beta \mathrm{P}$ in September, May and July is remained unclear. Future studies should be conducted with any other physiological role of $17 \alpha 20 \beta \mathrm{P}$ on males in this period.

In the present study, there was a significantly positive correlation between $17 \alpha 20 \beta \mathrm{P}$ and cortisol levels from female ribbed gunnel although there was no periodical change in cortisol levels from males. Moreover, cortisol levels from both females and males were also high in July when $17 \alpha 20 \beta \mathrm{P}$ levels were also high. These results suggested that cortisol may be involved in reproduction of ribbed gunnel. Classically, cortisol is mainly produced from interrenal tissue. Other studies reported that cortisol is also produced from ovary (Kusakabe et al., 2002; Kazeto et al., 2003; Zhou et al., 2007). These studies support the presence of corticosteroidogenesis in ovary. In earlier previous study, Mommsen and colleagues demonstrated that cortisol may suppress reproductive function; cortisol suppressed vitellogenin levels in plasma and vitellogenin synthesis from liver (Mommsen et al., 1999). However, Milla and colleagues reported that cortisol may involve in fish reproduction positively; the authors indicated that higher cortisol levels in mature stage than immature stage were reported with several fish species (Milla et al., 2009). In addition, cortisol could induce in vitro oocyte maturation followed volume increase by hydration and increase the expression of glucocorticoid receoptor (Milla et al., 2006). There also has been controversy in the function of cortisol in reproduction in other vertebrates. For examples, cortisol ex- hibited a positive action during ovulation in human (Jimena et al., 1992; Andersen, 2002) although it had no significant effect on oocyte maturation of mouse or it inhibited oocyte maturation of pig (Yang et al., 1999; Andersen, 2003). However, the present data are sufficient to evoke the functional action of cortisol on reproduction even though there are still controversies and we do have insufficient data about it.

In conclusion, changes in sex steroid levels in ribbed gunnels have annual periodicity and we suspect that $17 \alpha 20 \beta \mathrm{P}$ may regulate early oocyte development. Moreover, cortisol may involve in maturation process and act as an index for not only in stress response but in reproduction of ribbed gunnel.

\section{ACKNOWLEDGEMENT}

This study was funded by National Fisheries Research and Development Institute (RP-2012-AQ-114).

\section{REFERENCES}

Andersen CY (2002) Possible new mechanism of cortisol action in female reproductive organs: physiological implications of the free hormone hypothesis. J Endocrinol 173:211-217.

Andersen CY (2003) Effect of glucocorticoids on spontaneous and follicle-stimulating hormone oocyte maturation in mouse oocytes during culture. J Steroid Biochem Mol Biol 85:423-427.

Antonopoulou E, Tsikliras AC, Kocour M, Zlabek V, Flajshans M, Gela D, Piackova V, Scott AP (2011) Teleost maturation-inducing hormone, 17,20 $\beta$-dihydroxypregn-4-en-3-one, peaks after spawning in Tinca tinca. Gen Comp Endocrinol 172:234-242.

Bonga SEW (1997) The stress response in fish. Physiol Rev 77:591-625.

Borg B (1994) Androgens in teleost fishes. Comp Biochem Physiol 109C:219-245. 
Desjardins JK, Stiver KA, Fitzpatrick JL, Milligan N, Van der Kraak GJ, Balshine S (2008) Sex and status in a cooperative breeding fish: behavior and androgens. Behav Ecol Sociobiol 62:785-794.

Ebrahimi M, Scott AP, Kime DE (1996) Extragonadal production of 17,20-dihydroxy-4-pregnen-3-ones in vitro in cyprinid fish. Gen Comp Endocrinol 104: 296-303.

Fontain P, Migaud H, Mandiki R, Gardeur JN, Kestemont P, Fostier A (2003) Involvement of sex steroids in final stages of oogenesis in Eurasian perch, Perca fluviatilis. Fish Physiol Biochem 28:331-332.

García-López A, Anguis V, Couto E, Canario AVM, Cañavate JP, Sarasquete C, Martínez-Rodríguez G (2006) Non-invasive assessment of reproductive status and cycle of sex steroid levels in a captive wild broodstock of Senegalese sole Solea senegalensis (Kaup). Aquaculture 254:583-593.

Hoffmann JL, Oris JT (2006) Altered gene expression: a mechanism for reproductive toxicity in zebrafish exposed to benzo[a]pyrene. Aquat Toxicol 78:332-340.

Hwang IJ, Baek HJ (2010) Effects of nonylphenol and 2,2',4,6,6'-pentachlorobiphenyl on in vitro steroidogenesis in maturing oocytes of ribbed gunnel, Dictyosoma burgeri. Dev Reprod 14:115-121 (Korean with English abstract).

Jensen KM, Korte JJ, Kahl MD, Pasha MS, Ankley GT (2001) Aspects of basic reproductive biology and endocrinology in the fathead minnow (Pimephales promelas). Comp Biochem Physiol 128C:127-141.

Jimena P, Castilla JA, Peran F, Ramirez JP, Vergara F, Molina R, Vergara F, Herruzo A (1992) Adrenal hormones in human follicular fluid. Acta Endocrinol 127:403-406.

Jin YS, Han JI, Park CB, Lee CH, Kim BH, Baek HJ, Kim HB, Lee YD (2007) Reproductive cycle of ribbed gunnel, Dictyosoma burger. Kor J Ichthyol 19:8-15 (Korean with English abstract).

Kazeto Y, Ijiri S, Matsubara H, Adachi S, Yamauchi
K (2003) Molecular cloning and characterization of $3 \beta$-hydroxysteroid dehydrogenase $/ \Delta^{5}-\Delta^{4}$ isomerase cDNAs from Japanese eel ovary. J Steroid Biochem Mol Biol 85:49-56.

Kim YU, Myoung JG, Kim YS, Han KH, Kang CB, Kim JK (2001) The Marine Fishes of Korea, Hangul Publishing, Busan, pp 226-227 (Korean).

Kobayashi M, Aida K, Sakai H, Kaneko T, Asahina K, Ishii S (1987) Radioimmunoassay for salmon gonadotropin. Nippon Suisan Gakk 53:995-1003.

Koya Y, Soyano K, Yamamoto K, Obana H, Matsubara $\mathrm{T}$ (2003) Oocyte development and serum profiles of vitellogenin and steroid hormone levels in captive female Pacific herring Clupea pallasii during their first maturational cycle. Fish Sci 69:137-145.

Kusakabe M, Kobayashi T, Todo T, Mark LP, Nagahama Y, Young G (2002) Molecular cloning and expression during spermatogenesis of a cDNA encoding testicular $11 \beta$-hydroxylase ( $\left.\mathrm{P}^{4} 0_{11 \beta}\right)$ in rainbow trout (Oncorhynchus mykiss). Mol Reprod Dev 62:456-469.

Kusakabe M, Nakamura I, Young G (2003) $11 \beta$-hydroxysteroid dehydrogenase complementary deoxyribonucleic acid in rainbow trout: cloning, sites of expression, and seasonal changes in gonads. Endocrinology 144:2534-2545.

Larsson DGJ, Mayer I, Hyllner SJ, Forlin L (2002) Seasonal variations of vitelline envelope proteins, vitellogenin, and sex steroids in male and female eelpout (Zoarces viviparus). Gen Comp Endocrinol 125:184-196.

Matsuyama M, Adachi S, Nagahama Y, Matsuura S (1988) Diurnal rhythm of oocyte development and plasma steroid hormone levels in the female red sea bream, Pagrus major, during the spawning season. Aquaculture 73:357-372.

Migaud H, Mandiki R, Gardeur JN, Fostier A, Kestemont P, Fontaine P (2003) Synthesis of sex steroids in final oocyte maturation and induced ovulation in female Eurasian perch, Perca fluviatilis. Aquat Living Resour 16:380-388.

Milla S, Jalabert B, Rime H, Prunet P, Bobe J (2006) 
Hydration of rainbow trout oocyte during meiotic maturation and in vitro regulation by $17 \alpha, 20 \beta$ dihydroxy-4-pregnen-3-one and cortisol. J Exp Biol 209:1147-1156.

Milla S, Wang N, Madiki SNM, Kestemont P (2009) Corticosteroids: friends or foes of teleost fish reproduction? Comp Biochem Physiol 153A:242-251.

Miura C, Higashino T, Miura T (2007) A progestin and an estrogen regulate early stages of oogenesis in fish. Biol Reprod 77:822-828.

Modesto T, Canario AVM (2003) Morphometric changes and sex steroid levels during the annual reproductive cycle of the Lusitanian toadfish, Halobatrachus didactylus. Gen Comp Endocrinol 131:220-231.

Mommsen TP, Vijayan MM, Moon TW (1999) Cortisol in teleosts: Dynamics, mechanisms of action, and metabolic regulation. Rev Fish Biol Fish 9:211-268.

Mori H, Nakagawa M, Soyano K, Koya Y (2003) Annual reproductive cycle of black rockfish Sebastes schlegeli in captivity. Fish Sci 69:910-923.

Nagahama Y, Yoshikuni M, Yamashita M, Tanaka M (1994) Regulation of oocyte maturation in fish. In: Sherwood NM, Hew CL (ed) Fish Physiology, vol. 13. Academic Press, London, pp 393-439.

Noaksson E, Linderoth M, Gustavsson B, Zebühr Y, Balk L (2005) Reproductive status in female perch (Perca fluviatilis) outside a sewage treatment plant processing leachate from a refuse dump. Sci Total Environ 340:97-112.

Patiño R, Sullivan CV (2002) Ovarian follicle growth, maturation, and ovulation in teleost fish. Fish Physiol Biochem 26:57-70.

Sangalang GB, Freeman HC (1988) In vitro biosynthesis of $17 \alpha, 20 \beta$-dihydroxy-4-pregnen-3-one by the ovaries, testes and head kidneys of the Atlantic salmon Salmo salar. Gen Comp Endocrinol 69:406-415.

Schulz RW, Franca LR, Lareyre JJ, Legac F, Chiarini- Garcia H, Nobrega RH, Miura T (2010) Spermatogenesis in fish. Gen Comp Endocrinol 165:390-411.

Scott AP, Sheldrick FL, Flint APF (1982) Measurement of $17 \alpha, 20 \beta$-dihydroxy-4-pregnen-3-one in plasma of trout (Salmo gairdneri Richardson): Seasonal changes and response to salmon pituitary extract. Gen Comp Endocrinol 46:444-451.

Scott AP, Sumpter JP, Stacey N (2010) The role of the maturation-inducing steroid, 17,20 $\beta$-dihydroxypregn4-en-3-one, in male fishes: a review. J Fish Biol 76:183-224.

Shiogaki M, Dotsu Y (1972) Life history of the blennioid fish, Dictyosoma burgeri. Contrib Fish Exp Station Nagasaki Univ 34:21-38.

Stequert B, Rodriguez JN, Cuisset B, Le Menn F (2001) Gonadosomatic index and seasonal variations of plasma sex steroids in skipjack tuna (Katsuwonus pelamis) and yellowfin tuna (Thunnus albacares) from the western Indian ocean. Aquat Living Resour 14:313-318.

Westring CG, Ando H, Kitahashi T, Bhandari RK, Ueda H, Urano A, Dores RM, Sher AA, Danielson PB (2008) Seasonal changes in CRF-I and urotensin I transcript levels in masu salmon: correlation with cortisol secretion during spawning. Gen Comp Endocrinol 155:126-140.

Yang JG, Chen WY, Li PS (1999) Effects of glucocorticoids on maturation of pig oocytes and their subsequent fertilizing capacity in vitro. Biol Reprod 60:929-936.

Zhou LY, Wang DS, Shibata Y, Paul-Prasanth B, Suzuki A, Nagahama Y (2007) Characterization, expression and transcriptional regulation of P450c17-I and -II in the medaka, Oryzias latipes. Biochem Biophys Res Commun 362:619-625.

(Received 26 September 2012, Received in revised form 13 November 2012, Accepted 19 November 2012) 